\begin{tabular}{|l|l|l||}
\hline \multicolumn{2}{|c|}{ PublisherInfo } \\
\hline \hline PublisherName & $:$ & BioMed Central \\
\hline \hline PublisherLocation & $:$ & London \\
\hline \hline PublisherImprintName & $:$ & BioMed Central \\
\hline \hline
\end{tabular}

\title{
Insecticide resistance
}

\begin{tabular}{|l|l|l||}
\hline \multicolumn{2}{|c|}{ ArticleInfo } \\
\hline \hline ArticleID & $:$ & 4594 \\
\hline \hline ArticleDOI & $:$ & $10.1186 /$ gb-spotlight-20021001-01 \\
\hline \hline ArticleCitationID & $:$ & spotlight-20021001-01 \\
\hline \hline ArticleSequenceNumber & $:$ & 260 \\
\hline \hline ArticleCategory & $:$ & Research news \\
\hline ArticleFirstPage & $:$ & 1 \\
\hline \hline ArticleLastPage & $:$ & 2 \\
\hline \hline & & RegistrationDate : 2002-10-1 \\
\hline ArticleHistory & $:$ & OnlineDate \\
\hline \hline ArticleCopyright & $:$ & BioMed Central Ltd2002-10-1 \\
\hline \hline ArticleGrants & $:$ & \\
\hline \hline ArticleContext & $:$ & 130593311 \\
\hline \hline
\end{tabular}




\section{Jonathan B Weitzman}

Email: jonathanweitzman@hotmail.com

The molecular mechanisms underlying insecticide resistance are poorly understood. In the September 27 Science, Philip Daborn and colleagues report the involvement of a specific cytochrome P450 gene, called Cyp6gI, in the resistance of Drosophila melanogaster to the xenobiotic toxin DTT (Science, 297:2253-2256, September 27, 2002). Daborn et al. used a DNA microarray containing fragments of all 90 Drosophila P450 genes to screen a DTT-resistant strain. They found that the Cyp6gI gene is overexpressed 10 to 100-fold compared to sensitive strains. The P450 allele in resistant strains contained an insertion of an Accord transposable element in the 5' end of the Cyp6gI gene. To demonstrate that P450 expression is sufficient to confer insecticide resistance, Daborn et al. show that transgenic flies overexpressing Cyp6gI were resistant to DTT.

\section{References}

1. Science, [http://www.sciencemag.org]

2. Cytochromes P450 of insects: the tip of the iceberg 